\title{
ПОРІВНЯЛЬНО-ПРАВОВИЙ АНАЛІЗ КРИМІНАЛЬНОЇ ВІДПОВІДАЛЬНОСТІ ЗА РОЗГОЛОШЕННЯ ДЕРЖАВНОЇ ТАЕМНИЦІ ТА ЗА РОЗГОЛОШЕННЯ ВІДОМОСТЕЙ ВІЙСЬКОВОГО ХАРАКТЕРУ, ЩО СТАНОВЛЯТЬ ДЕРЖАВНУ ТАЕМНИЦЮ, АБО ВТРАТУ ДОКУМЕНТІВ ЧИ МАТЕРІАЛІВ, ЩО МІСТЯТЬ ТАКІ ВІДОМОСТІ
}

Виноградов А. К., Михайлуца М. І.

У cmammi розглянуто злочини, які передбачені $\mathrm{cm}$. 328 Кримінального Кодексу України, а саме «Розголошення державної таємниці», та сm. 422 Кримінального Кодексу України «Розголошення відомостей військового характеру, що становлять державну таємницю, або втрата документів чи матеріалів, що містять такі відомості». Зроблено порівняльний аналіз зазначених злочинів та запропоновано способи покращення кримінально-правових норм.

Ключові слова: кримінальна відповідальність, злочин, державна таємниця, інформація, секретність, національна безпека, військовослужбовці.

В статье рассмотрены преступления, предусмотренные сm. 328 Уголовного Кодекса Украины, а именно разглашение государственной тайны, и ст. 422 Уголовного Кодекса Украины «Разглашение сведений военного характера, составляющих государственную тайну, или потеря документов или материалов, содержащих такие сведения». Сделан сравнительный анализ указанных преступлений и предложены способы улучшения уголовно-правовых норм.

Ключевые слова: уголовная ответственность, преступление, государственная тайна, информация, секретность, национальная безопасность, военнослужащие.

The article considered crimes, what envisaged by the item 328 Criminal Code of Ukraine, namely: "disclosure of state secrets" and item 422 Criminal Code of Ukraine of "disclosure of military information constituting state secrets, or loss of documents or materials containing such information", the comparative analysis of these crimes was made and also we proposed some methods of improving criminal-law norms.

The criminal-law description of norms of Special part of the Criminal code of Ukraine has both for a theoretical analysis and for practical application large value, therefore and the questions, related to the decision and guard of state secret, and also by the legal institute of secret on the whole, from the same position of criminal right have the reflection in the section of XIV of Special part of the Criminal code of Ukraine "Crimes in the field of the guard of state secret, inviolability of state boundary, providing appeal and mobilization».

The state protects this type of information by criminalizing relevant criminal acts. Therefore, we draw our attention to the problems of correct criminal characterization, qualification and assessment of socially dangerous encroachments on the security of the state secrets. The article makes a comparative analysis of the composition of the crimes envisaged by items 328 and 422 of the Criminal Code of Ukraine, namely: "disclosure of state secrets" and "disclosure of military information consti-

Виноградов А. К., Михайлуца М. І., 2019 tuting state secrets, or loss of documents or materials containing such information". In this characteristic is very important to analysis of the subject of crime, which is discussed in more details in the article in comparison between the two crimes. According to the researching what was made in the article, certain directions of improvement of the criminal law norms of protection of state secret are suggested in.

Key words: criminal responsibility, crime, state secret, information, secrecy, national safety, servicemen.

Постановка проблеми та іï актуальність. Дедалі більшого значення набувають питання, пов'язані із визначенням та охороною державної таємниці, а також правовим інститутом таємниці загалом, у тому числі з позиції кримінального права. Держава охороняє цей вид інформації шляхом криміналізації відповідних злочинних дій у розділі XIV Особливої частини Кримінального кодексу України «Злочини у сфері охорони державної таємниці, недоторканності державних кордонів, забезпечення призову та мобілізації».

Кримінально-правова характеристика норм Особливої частини Нового Кримінального кодексу України має як для теоретичного аналізу, так і для практичного застосування велике значення. 3 огляду на це ми повинні звернути увагу на проблему правильної кримінально-правової характеристики, кваліфікації та оцінки суспільно небезпечних посягань на збереження державної таємниці.

Аналіз останніх досліджень і публікацій. Питання, які висвітлюються у роботі, були предметом дослідження таких науковців, як П.П. Андрушко, М.І. Бажанов, О.Ф. Бантишев, В.О. Навроцький, В.І. Олійник, М.І. Хавронюк, О.В. Шамара.

Мета статті - зробити кримінально-правовий аналіз злочину, який передбачений ст. 328 Кримінального Кодексу України, а саме «Розголошення державної таємниці», та ст. 422 Кримінального Кодексу України «Розголошення відомостей військового характеру, що становлять державну таємницю, або втрата документів чи матеріалів, що містять такі відомості». Необхідно розглянути заходи із запобігання злочинам у сфері охорони державної таємниці та знайти можливі напрями удосконалення кримінально-правових норм.

Виклад основного матеріалу. Відповідно до Закону України «Про державну таємницю» державна таємниця - це вид таємної інформації, що охоплює відомості у сфері оборони, економіки, зовнішніх відносин, дер- 
жавної безпеки і охорони правопорядку, розголошення яких може завдати шкоди життєво важливим інтересам України, які визнані в порядку, установленому цим Законом, державною таємницею та підлягають охороні з боку держави [1, ст. 1].

Державна таємниця - це найважливіші для України відомості в різних галузях їі життєдіяльності. Витік такої інформації загрожує як окремим сферам державних інтересів, так і національній безпеці України в цілому, тому охорона державної таємниці була й залишається складовою частиною загальної системи забезпечення національної безпеки України.

Отже, відповідно до Закону України «Про службу безпеки України» сьогодні одним з найважливіших завдань органів Служби безпеки України $\epsilon$ забезпечення збереження державної таємниці від розголошення різноманітними засобами й методами, у тому числі шляхом розслідування справ про факти розголошення державної таємниці й притягнення винних осіб до кримінальної відповідальності [2, ст. 24].

Серед обставин, що можуть негативно вплинути на обороноздатність держави, $\epsilon$ розголошення державної таємниці. 3 набуттям чинності новим Кримінальним кодексом України постає проблема правильної кримінально-правової оцінки суспільно небезпечних посягань на збереження секретної інформації. Новий Кримінальний кодекс України передбачає відповідальність за розголошення державної таємниці у статті 328 [3].

Саме тому хотілося б визначити конститутивні ознаки складу злочину, які передбачає ст. 328 Кримінального кодексу України, оскільки правильна оцінка певних обставин чи ознак злочину надає змогу правильно кваліфікувати злочин та перебачити певні помилки.

Однією з головних ознак складу злочину, передбаченого ст. 328 нового КК, $\epsilon$ предмет даного злочину - інформація, що становить державну таємницю [3]. Зазначимо, що предметом цього злочину є відомості, що становлять державну таємницю.

Таким чином, у визначенні державної таємниці існують такі ознаки:

1) обмеженість доступу до державної таємниці як виду таємної інформації, тобто відомості, що становлять таку таємницю, підлягають засекречуванню (обмеженню їх поширення і доступу до їх матеріальних носіїв);

2) значущість, важливість таких відомостей у певний проміжок часу для інтересів держави, тобто в разі розголошення державної таємниці національній безпеці України може бути завдана суттєва шкода (матеріальний критерій);

3) чітке визначення сфер, у яких може існувати державна таємниця (оборона, економіка, наука і техніка, зовнішні відносини, державна безпека й охорона правопорядку);

4) передбаченість відомостей, що становлять державну таємницю, Законом, тобто встановлення переліку таких відомостей у спеціальному правовому акті - Зводі, на підставі та в межах якого створюються розгорнуті переліки відомостей, що становлять державну таємницю (формальний критерій);

5) охорона такої секретної інформації державою, тобто встановлення на підставі чинного законодавства єдиного порядку забезпечення охорони зазначеної інформації державно-правовими засобами [4, с. 23].
Отже, якщо розголошена інформація не відповідає будь-якій з цих ознак, особа не підлягає кримінальній відповідальності за ст. 328 ККУ.

Звернемо увагу, що об'єктивна сторона злочину виявляється в розголошенні відомостей, що становлять державну таємницю. Діяння може виражатися як у дії, так і в бездіяльності, що призводить до того, що відомості стають надбанням сторонніх осіб. Саме тому дія може виражатися, наприклад, у розголошенні секретних даних у розмові, письмовому повідомленні, шляхом публікації у пресі тощо.

Отже, бездіяльність може полягати в недотриманні правил зберігання, використання, перевезення матеріалів, документів, коли створюється можливість ознайомлення з відомостями сторонніх осіб. Спосіб розголошення для кваліфікації значення не має.

Злочин вважається закінченим з моменту розголошення відомостей, коли вони стали відомі хоча б одній сторонній особі [5, с. 416].

Об'єктивно розголошення державної таємниці складається з трьох моментів, які потребують обов'язкового встановлення: 1) порушення певних вимог нормативних актів, які встановлюють порядок поводження з державною таємницею, що виявляється в дії або бездіяльності; 2) сприйняття відомостей, що становлять державну таємницю, сторонньою особою; 3) встановлення причинного зв'язку між порушенням винним установлених правил поводження з державною таємницею та їх сприйняттям сторонньою особою [4, с. 24].

Важливо, що суб'єктивна сторона цього злочину - це будь-яка форма вини, тобто умисел (прямий і непрямий) чи необережність (самовпевненість і недбалість). Обов'язковою ознакою вини $\epsilon$ усвідомлення суб'єктом того, що відомості, які розголошуються, становлять державну таємницю i доводяться до відома сторонніх осіб.

Зазначимо, що при вчиненні цього злочину розголошення відомостей, що становлять державну таємницю, не повинно мати ознак державної зради або шпигунства, які передбачені статтями 111 та 114 Нового Кримінального Кодексу України, тобто не повинно бути умисно спрямоване на спричинення шкоди основам національної безпеки України [5, с. 416].

Саме тому, характеризуючи ознаки суб'єкта розголошення державної таємниці, необхідно зазначити, що кримінальній відповідальності за розголошення державної таємниці за безпосередньою вказівкою закону підлягають тільки такі особи, яким конкретна секретна інформація була довірена або стала відома у зв'язку з виконанням службових обов'язків. Інакше кажучи, йдеться про спеціального суб'єкта злочину.

Отже, кримінальній відповідальності за розголошення відомостей, що становлять державну таємницю, підлягає фізична осудна особа, яка досягла на момент скоєння злочину 16-річного віку і має або мала допуск до державної таємниці, а також взяла на себе письмове зобов'язання щодо збереження (нерозголошення) секретної інформації, довіреної чи такої, що стала відомою у зв'язку з виконанням службових обов' язків.

Тобто суб'єкт злочину, який передбачає ст. 328 ККУ, $\epsilon$ спеціальним суб'єктом, оскільки це має бути особа, якій були довірені або стали відомі відомості у зв'язку з виконанням службових обов'язків [3, ст. 18]. 
Отже, розглядаючи суб'єкта та його ознаки, хочемо звернути увагу на таку категорію суб'єктів, як військовослужбовці.

Зазначимо, що військовослужбовці й прирівняні до них особи за розголошення відомостей невійськового характеру, що становлять державну таємницю, які були їм довірені або стали відомі у зв'язку з проходженням службийвиконаннямпокладенихнанихобов'язків, також несуть відповідальність за ст. 328 нового КК України.

Розглядаючи злочин, передбачений статтею 422 Кримінального Кодексу України, а саме «Розголошення відомостей військового характеру, що становлять державну таємницю, або втрата документів чи матеріалів, що містять такі відомості», зауважимо, що безпосереднім об'єктом цього злочину $\epsilon$ порядок зберігання відомостей, документів або матеріалів військового характеру, що становлять державну таємницю.

Військова таємниця - це вид державної таємниці, що охоплює відомості у сфері оборони. Віднесення відповідної інформації до військової таємниці здійснюється мотивованим рішенням Державного експерта з питань таємниць.

Військовослужбовці внаслідок специфіки обов'язків, які вони виконують, володіють широкими відомостями про види зброї, бойову техніку, що перебуває на озброєнні держави, та іншими секретними відомостями [6, с. 134].

Отже, суворе збереження державної таємниці $\epsilon$ однією з найважливіших вимог військової дисципліни, яка закріплена в тексті військової присяги та у військових статутах. Військовослужбовець зобов'язаний бути пильним, суворо зберігати державну та військову таємницю [7, ст. 11; 8, ст. 4].

Збереження державної таємниці спрямоване на забезпечення обороноздатності країни і постійної боєготовності армії та флоту. Розголошення відомостей військового характеру спричиняє тяжкі наслідки для безпеки держави та боєздатності їі збройних сил. 3 огляду на це зазіхання на встановлений порядок збереження державної таємниці передбачає високий ступінь суспільної небезпечності [6, с. 134].

До відомостей військового характеру, що становлять державну таємницю, належать відомості, які мають велике значення для оборонних інтересів держави та спеціально охороняються нею. Наприклад, це відомості про дислокацію, боєздатність, озброєння, спорядження, бойову підготовку, мобілізаційні та оперативні плани Збройних сил України.

Предметом злочину $є$ відомості військового характеру, що становлять державну таємницю, та документи чи матеріали, котрі їх містять.

Відзначимо, що предметом злочину згідно зі ст. 328 та ст. 422 Кримінального Кодексу України $\epsilon$ певні відомості, що становлять державну таємницю, але треба звернути увагу саме на характер цих відомостей, тому що при кваліфікації певного злочину це дуже важливо. 3 об'єктивної сторони злочин вчиняється шляхом розголошення відомостей військового характеру, що становлять державну таємницю (ч. 1 ст. 422), а також втрати документів або матеріалів, що містять цю таємницю, предметів, відомості про які становлять державну таємницю (ч. 2 ст. 422).

Тобто у випадках розголошення військовослужбовцем інших відомостей, які становлять державну таєм- ницю, втрати документів або матеріалів, що містять цю таємницю, предметів, відомості про які становлять державну таємницю, відповідальність для військовослужбовця, який скоїв злочин, настає вже за іншими статтями Кримінального кодексу України, а саме за ст. 328 та ст. 329 КК [6, с. 135].

Під розголошенням відомостей військового характеру, що становлять державну таємницю, слід розуміти протиправний їх розголос, внаслідок чого вони стали надбанням хоча б однієї сторонньої особи. Розголошення цих відомостей може полягати як в усному, так і в письмовому їх повідомленні, а також у показі або передачі документів і матеріалів, що становлять державну таємницю.

Зауважимо, що з об'єктивного боку скоєння обох злочинів, розглянутих вище, має спільне відображення діянь чи бездіяльності, тобто дії, певні відомості стають надбанням третьої особи та відбувається порушення певних нормативів, встановлених правил поводження з державною таємницею.

Суб'єктивна сторона розголошення відомостей військового характеру, що становлять державну таємницю, характеризується як умисною, так і необережною формою вини, а втрата документів або матеріалів, що містять відомості військового характеру, які становлять державну таємницю, предметів, відомості про які становлять державну таємницю, - тільки необережною формою вини. До настання тяжких наслідків суб'єкт ставиться необережно.

При порівняльному аналізі суб'єктивної сторони злочинів, передбачених ст. 328 та ст. 422 нового Кримінального кодексу України, виділяються однакові форми вини, в обох випадках спостерігається умисел та необережність, що вказує на схоже психічне ставлення особи до вчинюваної дії чи бездіяльності, передбаченої Кримінальним кодексом України [3, ст. 25].

Тяжкість наслідків, передбачених ч. 3 ст. 422, встановлюється з огляду на конкретні обставини. До них можна віднести випадки, коли розголошене стало відомим іноземним розвідкам і використовується ними на шкоду інтересам України.

Безпосереднім об'єктом цих злочинів $є$ встановлений порядок здійснення своїх повноважень військовими службовими особами Збройних сил України й інших військових формувань.

Суб'єктом злочину може бути військовослужбовець або військовозобов'язаний під час проходження зборів, якому документи або матеріали, що містять відомості військового характеру, котрі становлять державну таємницю, а також предмети, відомості про які становлять державну таємницю, були довірені, тобто військовослужбовець рядового, сержантського складу, військовослужбовець за контрактом, прапорщик, мічман і офіцер незалежно від службового становища [6, с. 136].

Відповідно до ст. 422 нового КК не може притягатися до відповідальності військовослужбовець у випадках втрати документів, предметів чи матеріалів, які містять державну таємницю військового характеру, якщо вони не були довірені йому по службі, а перебували у нього випадково [6, с. 136].

Що стосується суб'єкта злочину, то кримінальній відповідальності за розголошення відомостей, що становлять державну таємницю, підлягає фізична осудна особа, яка досягла на момент скоєння злочину 16-річ- 
ного віку і має або мала допуск до державної таємниці. Іншими словами, ідеться про спеціального суб'єкта злочину. У ч. 2 ст. 18 нового КК України наголошується: «Спеціальним суб'єктом злочину $є$ фізична осудна особа, що вчинила у віці, з якого може наставати кримінальна відповідальність, злочин, суб'єктом якого може бути лише певна особа».

Хоча відносно суб'єкта злочину, передбаченого ч. 2 ст. 422 нового ККУ, у тексті закону прямої вказівки немає, однак службове становище таких осіб свідчить про те, що вони також $\epsilon$ спеціальними суб'єктами, оскільки у зв'язку з виконанням службових обов'язків певній особі були довірені або стали відомі відповідні документи, матеріали чи предмети, а також ця особа взяла на себе письмове зобов'язання щодо збереження (нерозголошення) секретної інформації, довіреної чи такої, що стала відомою у зв'язку з виконанням службових обов'язків.

Висновки. Зробивши аналіз викладеного матеріалу, можна дійти висновку, що обидва злочини, передбачені ст. 328 та ст. 422 нового Кримінального Кодексу України, а саме «Розголошення державної таємниці» та «Розголошення відомостей військового характеру, що становлять державну таємницю, або втрата документів чи матеріалів, що містять такі відомості», $є$ досить схожими. Ознаки та обставини конкретного злочину $є$ дуже важливими для правильної кваліфікації злочинів щодо розголошення державної таємниці, а також для запобігання скоєнню подібних злочинів у майбутньому.

Саме тому дієвим засобом для покращення цього становища $\epsilon$ вдосконалення саме кримінально-правової норми, оскільки вже багато років вона $\epsilon$ незмінною. Першочергово необхідно звернути увагу на розміщення статті 328 ККУ у розділі XIV Особливої частини Кримінального кодексу України «Злочини у сфері охорони державної таємниці, недоторканності державних кордонів, забезпечення призову та мобілізації». 3 огляду на величезну значущість такої інформації як для внутрішньої, так і зовнішньої політики держави, можливо, доречнішим було б розмістити статтю 328 ККУ у іншому розділі особливої частини ККУ, а саме у І Розділі «Злочини проти основ національної безпеки України», тим самим підкреслюючи важливість збереження держаної таємниці для національної безпеки України. Це сприяло $б$ збільшенню різноманітності засобів та методів роз-
Протидія злочинності: проблеми практики та науково-методичне забезпечення

слідування справ про факти розголошення державної таємниці, притягнення винних осіб до відповідальності та своєчасному попередженню скоєння таких злочинів, тобто удосконаленню роботи Служби безпеки України.

\section{Література}

1. Про державну таємницю : Закон України від 21.01.1994p. № 3855-XII. Відомості Верховної Ради України. 1994 р. № 16. стор. 422. Стаття 93.

2. Про Службу безпеки України : Закон України від 25.03.1992 р. № 2229-XII. Відомості Верховної Ради України. 1992 р. № 27. Стаття 38.

3. Кримінальний кодекс України : Закон України від 05.04.2001 р. № 2341-III. Відомості Верховної Ради України. 2001 р. № 25. Стаття 131.

4. Шамсутдінов О. Відповідальність за розголошення державної таємниці за новим Кримінальним законодавством України. Правове, нормативне та метрологічне забезпечення системи захисту інформації в Україні. 2001. № 2. C. 21-25.

5. Кримінальне право України: особлива частина : підручник / Ю.В. Баулін, В.І. Борисов, В.І. Тютюгін та ін. ; за ред. В.В. Сташиса, В.Я. Тація. 4-те вид., переробл. і допов. Харків : Право, 2010. 608 с.

6. Злочини проти встановленого порядку несення військової служби (військові злочини) : навч. посіб. / Г.М. Анісімов, Ю.П. Дзюба, В.І. Касинюк та ін. ; за ред. М.І. Панова. Харків : Право, 2011. 184 с.

7. Про внесення змін до Закону України «Про Статут внутрішньої служби Збройних сил України» : Закон України. Відомості Верховної Ради України (ВВР). 1999. № 22-23. СТ. 194. URL: https://zakon.rada.gov.ua/laws/ show/548-14.

8. Про внесення змін до Закону України «Дисциплінарний статут Збройних Сил України» : Закон України. Відомості Верховної Ради України (ВВР). 1999. № 22-23. Ст. 197. URL: https://zakon.rada.gov.ua/laws/show/551-14.

Виноградов А. К., кандидат юридичних наук, доцент, доцент кафедри кримінального та адміністративного права Одеського національного морського університету

Михайлуча М. І., аспірантка кафедри кримінального та адміністративного права Одеського національного морського університету 